\title{
THE EVALUATION OF ANTIMICROBIAL AND CYTOTOXIC ACTIVITY OF THE ESSENTIAL OIL EXTRACTED FROM THE AERIAL PARTS OF SOUTHERNWOOD HERB (ARTEMISIA ABROTANUM L.) THAT RECENTLY GROWN IN IRAQ
}

\author{
SARAH S ALMAHDAWY ${ }^{1 *}$, ALI MUAFFAQ SAID ${ }^{2}$, IBRAHIM S ABBAS ${ }^{1}$, ASHOUR H DAWOOD ${ }^{3}$ \\ ${ }^{1}$ Department of Pharmacognosy and Medicinal Plants, College of Pharmacy, Al-Mustansiriya University, Baghdad, Iraq. ${ }^{2}$ Department of \\ Pharmacy, Al-Yarmouk University College, Baghdad, Iraq. ${ }^{3}$ Department of Pharmaceutical Chemistry, College of Pharmacy, Al-Mustansiriya \\ University, Baghdad, Iraq. Email: sara.saad.abd@gmail.com
}

Received: 02 August 2017, Revised and Accepted: 28 August 2017

\section{ABSTRACT}

Objective: This research is to study the assessment of the antimicrobial and cytotoxic activity of the essential oil extracted from the aerial parts of Artemisia abrotanum L. that recently grown in Iraq.

Methods: The essential oil of A. abrotanum was extracted by hydrodistillation using Clevenger apparatus. This essential oil was tested for antimicrobial activity of five different pathogenic microorganisms (Gram-positive [Staphylococcus aureus and Bacillus subtilis] and Gram-negative [Salmonella typhi and Escherichia coli] bacterial strains) and fungi: Candida albicans using diffusion well agar method. Furthermore, this essential oil was tested for cytotoxic activity using rhabdomyosarcoma cell line, and the growth or inhibition of cancer cells was measured by MTT method.

Results: The obtained results show that the antibacterial activity for $A$. abrotanum against $S$. aureus was at concentrations 40,25 , and $15 \mu \mathrm{l}$ with minimum inhibitory concentrations of $20 \mathrm{~mm}$, while it showed antibacterial activity against $E$. coli for four different concentrations of 40, 25, 15, and10 $\mu \mathrm{l}$ with inhibition zone of $16,12,14$, and $10 \mathrm{~mm}$, respectively, and it showed antifungal activity against $C$. albicans at four concentrations 40,25 , 15 , and $10 \mu \mathrm{l}$ with inhibition zone of $18,24,26$, and $30 \mathrm{~mm}$, respectively. The cytotoxic activity of the extracted essential oil was showed that the three concentrations of the extract $(25,50$, and $100 \mu \mathrm{g} / \mathrm{ml})$ were all lower significantly as compared to dimethyl sulfoxide group. A significant difference was seen for group 25 with both groups 50 and 100, but no significant difference was seen between the two later. Finally, the antimicrobial and anticancer activity of this plant could be due to its essential oil constituents: Borneol, cymene, camphor, terpineol, eucalyptol, and aromadendrene.

Conclusion: The essential oil of A. abrotanum L. has a potent antimicrobial and anticancer effect against the tested microbial organisms and the cancer cells.

Keywords: Southernwood, Artemisia abrotanum, Human rhabdomyosarcoma cell, (3-(4, 5-dimethyl-2-thiazolyl)-2, 5 diphenyl-2H tetrazolium bromide).

(c) 2017 The Authors. Published by Innovare Academic Sciences Pvt Ltd. This is an open access article under the CC BY license (http://creativecommons. org/licenses/by/4. 0/) DOI: http://dx.doi.org/10.22159/ajpcr.2017.v10i10.21725

\section{INTRODUCTION}

The genus Artemisia L. is among the largest and most widely spread genera of the Asteraceae family, consisting of 522 small herb and shrub species native to the Northern Hemisphere, South America, Southern Africa, and the Pacific Islands [1]. Artemisia abrotanum (southernwood) is a shrubby perennial plant, the height and width 3-5 feet, it consists of yellowish-white flowers, and has a fragrance similar to cola or tangerine [2]. Plants are an important source of important compounds for the development of new chemotherapeutic agents. In vitro evaluation of plants for the antimicrobial property is the first step toward achieving the aim for developing eco-friendly management of infectious diseases of humans by searching for new biomolecules of plant origin [3].

Essential oils play an important role in the biological activity of the plant; they were mostly composed of terpenes and are obtained by means of steam distillation, hydro distillation, or solvent extraction of different parts of the aromatic plants [4]. A. abrotanum was traditionally used as an antiseptic, astringent, emmenagogue, antidiabetic, expectorant, febrifuge, stomachic, antimalarial, anti-inflammatory, vermifuge, and spasmolytic and used for treating upper respiratory tract disease, antibacterial, antifungal, cancer, cough, and fever [5]. In Iraq, there is no study about $A$. abrotanum essential oil biological activity because this plant was introduced recently to Iraq for decorative purposes.

\section{METHODS}

Plant collection

The plant aerial parts of A. abrotanum were collected from Iraq at September from the botanical garden in College of Pharmacy at AlMustansiriya University. The plant was authenticated by National Iraqi Herbarium, Botany Directorate at Abu-Ghraib. The aerial parts were dried in the shade at room temperature for 7 days until crisp and then were grinded by mechanical mills and weighed (Fig. 1).

Isolation procedure

The essential oil content of $A$. abrotanum was extracted by hydro distillation method by the use of Clevenger apparatus, $100 \mathrm{~g}$ of the plant material were hydrodistilled by adding $500 \mathrm{ml}$ of distilled water in round flask bottom, the plant was left boiling for $3 \mathrm{hrs}$, and the volatile oil was collected after observing that there is no increase in volatile oil amount. Anhydrous sodium sulfate was added to the essential oil in the cylinder to remove any water left. Then, it was kept into tightly closed, dark, small, glass containers and kept into the refrigerator and stored at $4^{\circ} \mathrm{C}$. The average percentage of volatile oil content of the plant sample was calculated by $\mathrm{V} / \mathrm{W}$ of dried plant materialwhich was $0.5 \%$.

\section{Antimicrobial activity of $A$. abrotanum}

The essential oil of $A$. abrotanum was tested for antimicrobial activity of five different pathogenic microorganisms gram positive: [Staphylococcus 


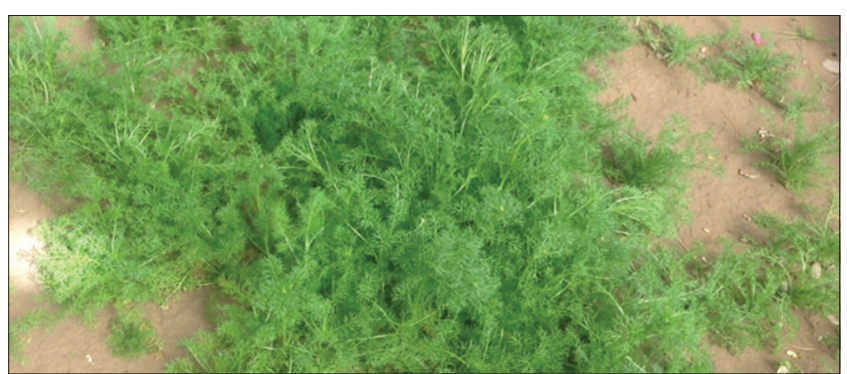

Fig. 1: The effects of $A$. abrotanum on RD cell viability (statistical analysis)

aureus (S.aureus), Bacillus subtilis(B.subtilis)], gram negative: [Salmonella typhi (S.typhi), Escherichia coli (E.coli)] bacterial strains and fungi: Candida albicans (C.albicans) by using diffusion well agar method [6]; then, the growth or inhibition of bacterial cells was determined by zone inhibition diameter. The Petri dishes were washed and placed in autoclave; then, after sterilization, the medium (Nutrient agar, Macconkey agar, Salmonella Shigella agar, and Yeast agar) was poured into each Petri dish and allowed to solidify in laminar air flow chamber, and using sterile cotton swab, a bacterial culture was spread over the Petri dish by spread plate technique, and the gel puncture method done using the sterile cork borer to make wells of $6 \mathrm{~mm}$ size in the agar of each plate (the bacteria with dimethyl sulfoxide [DMSO] consider as negative control). Then, $1 \mathrm{ml}$ of bacterial suspension was added in each plate. Beside of this, positive control (medium with bacterium with extract) also was prepared. For determination of minimum inhibitory concentrations (MIC), serial dilutions of the essential oil of both species of artemisia were done using a micropipette $(40,30,25,20,15$, and $10 \mu \mathrm{l})$ onto each well on all plates. Finally, they were incubated at $37 \mathrm{C}$ for $24 \mathrm{hrs}$, the plates were observed for the formation of clear inhibition zone around the well which indicate the presence of antimicrobial activity, and the inhibition zone measured by diameter.

\section{Cytotoxic activity of $A$. abrotanum L. in cancer tissue culture}

Cell cultures in 96-well plate were exposed to three different concentrations of plant extracts (essential oil) during the log phase of growth and the effect determined after recovery time [7], all solutions and procedures prepared according to Freshney [8]. The first stage is cell seeding. Cell suspension was prepared using $25 \mathrm{~cm}^{3}$ tissue culture flask with $2 \mathrm{ml}$ trypsin solution incubated for 2 minutes at $37^{\circ} \mathrm{C}$ in an incubator supplied with $5 \% \mathrm{CO}_{2}$ after detachment of the cells from the flask surface single cell suspension by gently taping of the flask followed by the addition of $20 \mathrm{ml}$ of growth medium supplemented with $10 \%$ fetal calf serum. Then, transferring about $200 \mu \mathrm{l} /$ well of the 96 -well flatbottom microtiter plate using automatic micropipette containing $1 \times 10^{5}$ cell/well. Plates were incubated at $37^{\circ} \mathrm{C}$ in an incubator supplemented with (5\%) $\mathrm{CO}_{2}$ until $60-70 \%$ concourse of the internal surface area of the well for RD cell line, and the second stage (exposure stage), the cells were then exposed to three different concentrations $(25,50$, and $100 \mu \mathrm{l}$ of $1 \mu \mathrm{g} / \mathrm{ml}$ ) of the essential oil, the mixture was added to the cells in six wells of each concentration, the cells that incubated with vehicle or methotrexate represented the negative control and positive control, respectively, and then, the 96 -well cell culture plate incubated at $37^{\circ} \mathrm{C}$ in an incubator supplemented with $5 \% \mathrm{CO}_{2}$ for $24 \mathrm{hrs}$. After elapsing, the incubation period $10 \mu \mathrm{l}$ of a mitogen solution (PHA) and the proposed drugs solutions were added, and the plate was further incubated for $24 \mathrm{hrs}$ at $37^{\circ} \mathrm{C}$ in a humidified $5 \% \mathrm{CO}_{2}$ atmosphere. Then, $50 \mu \mathrm{l}$ of MTT working solution $(5 \mathrm{mg} / \mathrm{ml})$ were added to each culture well, and the cultures were incubated for $4 \mathrm{hrs}$ at $37^{\circ} \mathrm{C}$ in a humidified $5 \% \mathrm{CO}_{2}$ atmosphere. The MTT is a colorimetric assay to assess cell counts and cytotoxicity by measures the reduction of a tetrazolium (MTT) into an insoluble formazan product. Tetrazolium ring is cleaved by NAD (P) $\mathrm{H}$-dependent oxidoreductase enzymes in active mitochondria, and therefore, the reaction occurs only in living cells $[9,10]$. After that, the culture medium was removed from wells, and the converted dye was solubilized with $100 \mu \mathrm{l}$ of acidic isopropanol (absolute isopropanol supplemented with $0.04 \mathrm{~N} \mathrm{HCl}$ ). The absorbency of the wells was measured with a microculture plate reader at $570 \mathrm{~nm}$. The optical density (OD) and the viability rate were determined.

\section{Statistical analysis}

The data of cytotoxic activity results were performed using SPSS 16.0 version, using analysis of variance. Data were presented as means \pm standard deviation $(S D)$. The level of significance $(p<0.05)$ was used for analysis of results presented in this study.

\section{RESULTS AND DISCUSSION}

\section{The antimicrobial effects of $A$. abrotanum $\mathrm{L}$.}

The results showed in Table 1 indicated that the antibacterial activity for A. abrotanum against $S$. aureus was at concentration 40,25, and $15 \mu \mathrm{l}$ with MIC of $20 \mathrm{~mm}$, while it showed antibacterial activity against E. coli for four different concentrations of $40,25,15$, and $10 \mu \mathrm{l}$ with inhibition zone of $16,12,14$, and $10 \mathrm{~mm}$, respectively. These findings could be explained the results for A. abrotanum in Table 1 of our work, although there are limited studies available, the plant was also showed antimicrobial activity against both types of bacteria, in which is compatible with the previous studies [11,12], could be due to that it contains borneol, cymene, camphor, terpineol, and eucalyptol that have antibacterial activity.

Furthermore, the results showed that this plant has antifungal activity against $C$. albicans at four concentrations $(40,25,15$, and $10 \mu \mathrm{l}$ ) with inhibition zone of $18,24,26$, and $30 \mathrm{~mm}$, respectively. The antibacterial activity may be attributed to the essential oil constituents such as: camphor which shows a very potent antimicrobial activity against S.aureus and C. albicans [13], borneol that has antibacterial activity against different types of gram positive and gram negative organisms [14], cymene that exhibit antibacterial activity against S. aureus, E. coli [15], Bisabolene that demonstrate the antibacterial activity against $S$. aureus, E.coli, Pseudomonas aeruginosa [16], aromadendrene that appear antibacterial activity against multidrugresistant bacterial pathogens [17], most of the essential oils that contain terpenes are reported to have antimicrobial activity [18]. Several studies are available for the antifungal effects that could explained our results, and for $A$. abrotanum, the plant showed that activity against C. albicans [19]. These effects could be due to the active constituents that in the essential oil of the plant which they have an antifungal action such as borneol [20] and camphor [21], which may be explained the results in this work.

\section{The cytotoxic activity of $A$. abrotanum $\mathrm{L}$}

The result of cytotoxic activity of A.abrotanum is shown in Graph 1 below [22].

\section{The effects of A. abrotanum on RD cell viability:}

- Values are mean $\pm \mathrm{SD}$ of RD growth viability.

- Non-identical subscripts (a, b, c, and d) with different colored bars consider significantly different $\mathrm{p}<0.05$ when compared between the three concentrations of each extract and with both negative and positive controls.

The results showed that the group of methotrexate decreased significantly in $-42 \%$ as compared to the negative control group of DMSO only. The three concentrations of the essential oil extracts $(25,50$, and $100 \mu \mathrm{g} / \mathrm{ml})$ were all higher significantly in growth viability as compared to methotrexate group. The three concentrations of the extract $(25,50$, and $100 \mu \mathrm{g} / \mathrm{ml})$ were all lower significantly as compared to DMSO group. A significant difference was seen for group 25 with both groups 50 and 100, but no significant difference was seen between the two later. The results obtained in this work were compatible with the previous studies before. The plant artemisia was showed anticancer effects for several different species.

This anticancer activity may be due to the active constituents present in the essential oil [13], such as Limonene that show cytotoxicity against 


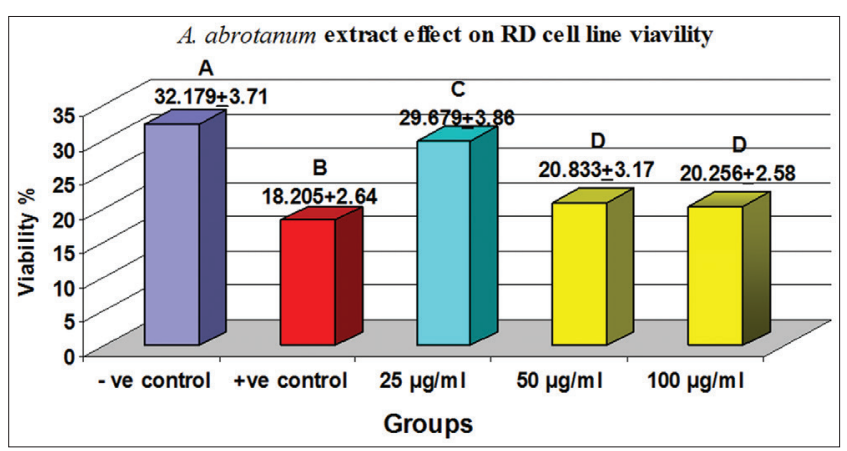

Graph 1: The effects of $A$. abrotanum on RD cell viability (statistical analysis)

Table 1: Antibacterial activity of A. abrotanum

\begin{tabular}{llll}
\hline $\begin{array}{l}\text { Concentrations } \\
\text { of essential oil of } \\
\text { A. abrotanum }(\boldsymbol{\mu l})\end{array}$ & $\begin{array}{l}\text { S. aureus } \\
(\mathbf{m m})\end{array}$ & $\begin{array}{l}\text { E. coli } \\
(\mathbf{m m})\end{array}$ & $\begin{array}{l}\text { C. albicans } \\
(\mathbf{m m})\end{array}$ \\
\hline 40 & 20 & 16 & 18 \\
30 & - & - & - \\
25 & 24 & 12 & 24 \\
20 & - & - & - \\
15 & 28 & 14 & 26 \\
10 & - & 10 & 30 \\
\hline
\end{tabular}

A. abrotanum: Artemisia abrotanum, S. aureus: Staphylococcus aureus,

E. coli: Escherichia coli, C. albicans: Candida albicans

breast carcinoma [23], and Mayurone that has anticancer against (MCF-7) cells [24], Borneol that exhibit cytotoxic activity against (HepG2, Caco-2 and VH10) cell lines [25], Bisabolene that demonstrate cytotoxic activity against breast cancer [26], Cymene that has cytotoxic activity against (HepG2, K562, and B16-F10) cell lines [27], Camphor that appear cytotoxic activity against MRC-5, HT-29 and HCT 116 cell lines [28].

Plants have been a prime source of highly effective conventional drugs for the treatment of many forms of cancer. In many situations, the actual compound isolated from the plant may not serve as the drug but leads to the development of potential novel agents. The ability to attach agents to carrier molecules directed to specific tumors holds promise for the effective targeting of highly cytotoxic natural products to the tumors while avoiding their toxic side effects on normal healthy tissues [29].

\section{CONCLUSION}

The essential oil of A. abrotanum that recently grows in Iraq extracted by hydro distillation has a potent antimicrobial and anticancer effect against the tested microbial organisms and the cancer cells. The essential oil from this plant shows several biological activities, and more researches are required to study the biologic activities for each active constituents that obtain in this study. The essential oil shows several biological activities, more researches are required to study the biologic activities for each active constituents that obtain in this study, and finally, the essential oil in this study showed marked anticancer activity, more researches are required for further assessment of this effect against other different types of cancers, both in vitro and in vivo.

\section{REFERENCES}

1. Hussien HA, Hussein MS, Tkachenko KG, Nkomo M, Mudau FN. Essential oil composition of $A$. vulgaris grown in Egypt. Int J Pharm Pharm Sci 2016;8(9):120-3.

2. Amirmohammadi M, Khajoenia S, Bahmani M, Kopaei MR, Eftekhari Z, Qorbani M. In vivo evaluation of antiparasitic effects of Artemisia abrotanum and Salvia officinalis extracts on Syphacia obvelata, Aspiculoris tetrapetra and Hyenolepis nana parasites. Asian Pac J Trop Dis 2014;4(1):250-4.
3. Ibrahim NM. Extraction and characterization of Iraqi Artemisia dracunculus dried aerial parts extract though HPLC and GC-MS analysis with evaluation of its antitumor activity against 7, 12-dimethyl benzene (a) anthracene induced skin cancer in mice. Int J Pharm Pharm Sci 2017;9(5):34-2.

4. Coelho JP, Cristion AF, Matos PG, Ratuter AP, Nober BP, Mendes RL, et al. Extraction of volatile oil from aromatic plants with supercritical carbon dioxide: Experiments and modeling. Molecules 2012;17(9):10550-73.

5. Suresh J, Reddy AV, Rajan D, Ihsanullah M, Khan MN. Antimicrobial activity of Artemisia abrotanum and Artemisia pallens. Int J Pharm Pharm Res 2011;3(2):18-21.

6. Suganya S, Bharathidasan R, Senthilkumar G, Madhanraj P, Panneerselvam A. Antibacterial activity of essential oil extracted from Coriandrum sativum (L.) and GC-MS analysis. J Chem Pharm Res 2012;4(3):1846-50.

7. Gordanian B, Behbahani M, Carapetian J, Fazilati M. In vitro evaluation of cytotoxic activity of flower, leaf, stem and root extracts of five Artemisia species. Res Pharm Sci 2014;9(2):91-6.

8. Sadeghi H, Ghasemi N, Kohi M. Cytotoxic effect of Convolvulus arvensis extracts on human cancerous cell line. Res Pharm Sci 2008;3(1):31-4.

9. Mosmann T. Rapid colorimetric assay for cellular growth and survival: Application to proliferation and cytotoxicity assays. J Immunol Methods 1983;65(1-2):55-63.

10. Berridge MV, Tan AS. Characterization of the cellular reduction of 3-(4,5-dimethylthiazol-2-yl)-2,5-diphenyltetrazolium bromide (MTT): Subcellular localization, substrate dependence, and involvement of mitochondrial electron transport in MTT reduction. Arch Biochem Biophys 1993;303(2):474-82.

11. Obistioiu D, Cristina RT, Schmerold I, Chizzola R, Stolze K, Nichita L, et al. Chemical characterization by GC-MS and in vitro activity against Candida albicans of volatile fractions prepared from Artemisia dracunculus, Artemisia abrotanum, Artemisia absinthium and Artemisia vulgaris. Chem Central J 2014;8(6):1-11.

12. Alama HE, El-Aissamil AE, Said AA, Alaoui-Faris FE. Evaluation of anti - Candida albicans activity of essential oils of six medicinal plants: Synergy concept. J Chem Pharm Res 2015;7(10):281-4.

13. Mahboubi M, Kazepour N. The antimicrobial activity of essential oil from Perovskia abrotanoides Karel and its main components. Indian J Pharm Sci 2009;71(3):343-7.

14. Tabanca N, Kirimer N, Demirci B, Demirci F, Baser KH. Composition and antimicrobial activity of the essential oils of Micromeria cristata subsp. Phyrgia and the enantiomeric distribution of borneol. J Agric Food Chem 2001;49:4300-3.

15. Marchese A, Arciola CR, Barbieri R, Silva AS, Nabavi SF, Sokeng AJ. Update on monoterpenes as antimicrobial agents: A particular focus on p-cymene. Materials 2017;10:1-15

16. Yamani HA, Pang EC, Mantri N, Deighton MA. Antimicrobial activity of tulsi (Ocimum tenuiflorum) essential oil and their major constituents against three species of bacteria. Front Microb 2016;7:681.

17. Mulyaningsih S, Sporer F, Reichling J, Wink M. Antibacterial activity of essential oils from Eucalyptus and of selected components against multidrug-resistant bacterial pathogens. Pharm Biol 2011;49(9):893-9.

18. Dorman HJ, Deans SG. Antimicrobial agents from plants: Antibacterial activity of plant volatile oils. J Appl Microbiol 2000;88:308-16.

19. Mokbel AA, Alharbi AA. Antifungal effects of basil and camphor essential oils against Aspergillus flavus and A. parasiticus. Aust J Crop Sci 2015;9(6):532-7

20. Bayala B, Bassole IH, Scifo R, Gnoula C, Morel L, Lobaccaro JM, et al. Anticancer activity of essential oils and their chemical components - A review. Am J Cancer Res 2014;4(6):591-607.

21. Kang SH, Kim EK, Kim YS, Hwang JW, Jeong JH, Dong X, et al. Anticancer activity of thymol on AGS human gastric carcinoma cells. J Microb Biotechnol 2016;26(1):28-37.

22. Saleh AM, Aljada A, Rizvi SA, Nasr A, Alaskar AS, Williams JD. In vitro cytotoxicity of Artemisia vulgaris L. essential oil is mediated by a mitochondria-dependent apoptosis in HL-60 leukemic cell line. BMC Complement Altern Med 2014;14:226.

23. Sobral MV, Xavier AL, Lima TC, De Sousa DP. Antitumor activity of monoterpenes found in essential oils. ScientificWorldJournal 2014;2014:953451.

24. Xu GL, Geng D, Xie M, Teng KY, Tian YX, Liu ZZ, et al. Chemical composition, antioxidative and anticancer activities of the essential Oil: Curcumae rhizoma-Sparganii rhizoma, a traditional herb pair. Molecules 2015;20(9):15781-96.

25. Sálmenova D, Horváthová E, Wsólová L, Sramková M, Navarová J. 
Investigation of anti-oxidative, cytotoxic, DNA-damaging and DNA-protective effects of plant volatiles eugenol and borneol in human-derived HepG2, Caco-2 and VH10 cell lines. Mutat Res 2009;677(1-2):46-52.

26. Yeo SK, Ali AY, Hayward OA, Turnham D, Jackson T, Bowen ID, et al. $\beta$-bisabolene, a sesquiterpene from the essential oil extract of opoponax (Commiphora guidottii), exhibits cytotoxicity in breast cancer cell lines. Phytother Res 2016;30(3):418-25.

27. Bourgou S, Pichette A, Marzouk B, Legault J. Bioactivities of black cumin essential oil and its main terpenes from Tunisia. S Afr J Bot 2010;76:210-6.

28. Nikolić B, Vasilijević B, Mitić-Ćulafić D, Gačić BV, Vukćević JK. Comparative study of genotoxic, antigenotoxic and cytotoxic activities of monoterpenes camphor, eucalyptol and thujone in bacteria and mammalian cells. Chem Biol Interact 2015;242:263-71.

29. Alex AR, Ilango K. In vitro cytotoxic activity of isolated compounds from Viburnum punctatum bush-ham ex d.don. Int J Curr Pharm Res 2017;9(1):85-7. 